\title{
Ultra-fast Detection and Differentiation of Mycoplasma haemofelis and Candidatus M. Haemominutum in Korean Feral Cats by Microchip Electrophoresis with Programmed Field Strength Gradients
}

\author{
Kailasa S. Kumar, Hee Gu Lee, ${ }^{\dagger}$ Dong Jin Yoo, ${ }_{+}^{\ddagger}$ and Seong Ho Kang ${ }^{\dagger}$ \\ Department of Chemistry and Basic Science Research Institute. Chonbuk National Cniversin, Jeonju 561-756. Korea \\ E-mail: shkangachonbuk.ac.k" \\ ${ }^{\dagger}$ Cellomics Research Center, Korea Research Institute of Bioscience and Biotechnologv (KRIBB). Daejeon 305-806. Korea \\ -Department of Chemistr., Seonam Cniversin, Namion $590-711$. Korea \\ Received July 30, 2007
}

\begin{abstract}
A microchip-based capillary gel electrophoresis (MCGE) technique was developed for the ultra-fast detection and differentiation of Candidatus Mycoplasma haemoninutum (Candidatus M. haemoninutum. California strain) and Hicoplasma haemofelis (M. haemofelis, Ohio strain) in Korean feral cats through the application of programmed field strength gradients (PFSG) in a conventional glass double-T microchip. The effects of the poly (ethy leneoxide) (PEO) concentration and electric field strength on the separation of DNA fragments were investigated. The PCR-amplified products of Candidatus M. haemoninutum (202-bp) and 1 . haemofelis (273bp) were analyzed by MCGE within $75 \mathrm{~s}$ under a constant applied electric field of $117.6 \mathrm{~V} / \mathrm{cm}$ and a sieving matrix of $0.3 \%$ PEO $\left(M_{\mathrm{L}} 8000000\right)$. When the PFSG was applied. MCGE analy sis generated results 6.8 -times faster without any loss of resolution or reproducibility. The MCGE-PFSG teclunique was also applied to eleven samples selected randomly from 33 positive samples. The samples were detected and differentiated within 11 $\mathrm{s}$. The analysis time of the MCGE-PFSG technique was approximately 980-times faster than that using conventional slab gel electrophoresis.
\end{abstract}

Key Words : Chip technology. Feline hemobartonellosis. Polymerase chain reaction. Programmed field strength gradients

\section{Introduction}

Hoemobartonella felis (H. felis) is a small epicellular bacterial parasite of feline erythrocytes and the most common cause of hemolytic anemia in cats. ${ }^{1}$ However. reports on the DNA sequences of $\mathrm{H}$. felis suggested the existence of two morphologically and genetically distinct genotypes of H. felis: the larger form called the 'Ohio strain' and the smaller form called the 'California strain'?' These species have been reclassified and renamed as $M$. haemofelis (for the larger form) and Condidatus M. haemominutum (for the smaller form), and are now collectively referred to as feline hemoplasmas. ${ }^{3}$

Many diagnostic and epidemiological studies of $\mathrm{H}$. felis infections in cats in various countries have been performed. Tasker and Lappin reviewed and described different types of $\mathrm{H}$. felis in various countries. and explained the superiority of the polymerase chain reaction (PCR) in diagnosing $\mathrm{H}$. felis in cats. ${ }^{3}$ Moreover the advantages of PCR for the sensitive and specific detection of Candidatus $\mathrm{M}$. haemominutum and M. haemofelis from naturally infected cats by slab gel electrophoresis have been reported. ${ }^{+6}$ After amplication of the specific fragments. the confirmation of the PCR products is indispensable because the slab gel electrophoresis technique has notable faults. including a slow analysis rate. a high material cost and difficulty in finding heterozygous DNA. In addition. this teclunique is labor-intensive and timeconsuming. It also requires multiple sample manipulation steps. As a result the analytical speed is very slow. Therefore. a more automated. reliable, user-friendly, ultra-fast and sensitive analytical method is needed.

Microchip electrophoresis (ME) is considered to be a revolutionary leap in analytical instrumentation. ME has many advantages for the analysis of PCR products. DNA restriction fragments. DNA sequencing and genotyping with regard to speed. reagent consumption and sensitivity. This technique is expected to be easily integrated with other laboratories for the analysis of biological molecules. such as PCR products. immobilized enzymatic reactions and single molecule dynamics. in order to explain the sizes of the DNA molecules and solve biological problems within a short time. ${ }^{11-13}$ Recently, our group reported the advantages of the ME with programmed field strength gradients for the ultrafast analysis of PCR products. ${ }^{14.15}$ this allows the rapid separation and enlanced separation efficiency of the target DNA fragments with a specific size. There has been no report on the application of ME with programmed field strength gradients to $\mathrm{H}$. felis in Korea. To our knowledge. this is the first report of the application of the MCGE-PFSG technique to the ultra-fast detection and differentiation of Candidants M. haemominutum and $M$. haemofelis in feral cats.

\section{Experimental Section}

Chemicals and reagents. A $1 \times$ TBE buffer $(0.089 \mathrm{M}$ Tris. 
$0.089 \mathrm{M}$ borate and $0.002 \mathrm{M}$ EDTA. $\mathrm{pH} 8.31$ ) was prepared by dissolving a pre-mixed powder (Amerosco. Solon, $\mathrm{OH}$. USA) in deionized water. A dynamic coating matrix of the microchip was made by dissolving $0.5 \%(\mathrm{w} / \mathrm{v})$ polyvinylpyrrolidone (PVP. $M_{\ulcorner} \mathrm{I} 000000$ ) (Poly science, Warrington. England) in a $\mathrm{I} \times \mathrm{TBE}$ buffer containing $0.5 \mu \mathrm{g} / \mathrm{mL}$ ethidium bronide (EtBr) (Sigma Chenicals. St. Louis, MO, USA). The mixture was shaken for $2 \mathrm{~min}$ and left to stand for $2 \mathrm{~h}$ to remove any bubbles. The sieving matrix was made by dissolving $0.3 \%(\mathrm{w} / \mathrm{v})$ of $M_{\mathrm{\top}} 8000000 \mathrm{PEO}$ (Signa Chemicals. St. Louis. MO, USA) in a $1 \times$ TBE buffer containing $0.5 \mu \mathrm{g} /$ $\mathrm{mL} \mathrm{EtBr}$, with gentle stirring overnight. A 100-bp DNA ladder (72 ng/ $\mu \mathrm{L}$ ) (Genepia, Korea) was used in electrophoresis

Clinical sample collection. A total of 331 samples of feline blood. which were obtained during a Trap-NeuterReturn (TNR) program in Seong-Nam city in Korea from March to October 2006. were examined using a PCR assay. The blood samples were collected by jugular venipuncture into an ethylene dianinetetraacetic acid (EDTA) anticoagulant tube. The samples were stored at $-20^{\circ} \mathrm{C}$ and transported periodically to the laboratory with a cold pack for analy sis

DNA extraction and PCR amplification of the 16S rRNA. DNA extraction was carried out using a GENE ALL ${ }^{\mathrm{TM}}$ Blood Total DNA Purification kit (general bio system. Korea) according to the manufacturer's instructions. The extracted DNA was stored at $-20{ }^{\circ} \mathrm{C}$ and used as a template for the PCR assay. The M. felis of the I6S rRNA gene was used to amplify the primers (Fig. 1). The following primers were used to amplify a 273-bp product from $M$. haemofelis: forward primer, 5'-ATG CCC CTC TGT GGG GGA TAG CCG-3'; and reverse primer, 5'-ATG GTA TTG CTC CAT CAG ACT TTC G-3'. The following primers were used to amplify a 202-bp amplicon from 'Candidonts M. haemominutum': forvard primer, 5'-CTG GGA AAC TAG AGC TTC GCG AGC-3': and reverse primer, 5'-ATG GTA TTG CTC CAT CAG ACT TTC G-3'. The PCR assay was optimized. yielding the following reaction conditions: initial denaturation for $5 \mathrm{~min}$ at $94^{\circ} \mathrm{C}$. followed by $35 \mathrm{cycles}$ of $45 \mathrm{~s}$ denaturation at $94^{\circ} \mathrm{C}, 45 \mathrm{~s}$ primer annealing at $58^{\circ} \mathrm{C}$, and $45 \mathrm{~s}$ extension at $72^{\circ} \mathrm{C}$. The template DNA $(2 \mathrm{~mL})$ was added to $48 \mathrm{~mL}$ of the reaction mixture containing $34.75 \mathrm{~mL}$ of sterile ultra-pure water, $5.0 \mathrm{~mL}$ of $\mathrm{I} 0 \times \mathrm{PCR}$ buffer, $4 \mathrm{~mL}$ of deoxynucleotide triphosphates (dNTPs) mixture $(2.5 \mathrm{mM}$ each) $1.5 \mathrm{~mL}$ of each primer $(20 \mathrm{pmol} / \mathrm{mL})$ and $0.75 \mathrm{~mL}$ of Toq DNA polymerase ( $5 \mathrm{U} / \mathrm{mL}$, iNtRON, Korea). The $M$. haemofelis (Genebank accession no. U88563) and 'Condickotus M. haemominutum' (Genebank accession no. U88564) DNA (kind gifts from Dr. Watanabe. University of Azabu, Japan) were included as positive controls in each PCR run to monitor the PCR reaction.

Cloning, nucleotide sequencing and phylogenetic analysis. The PCR amplicons were purified using a GFX ${ }^{\mathrm{N}} \mathrm{PCR}$ DNA purification kit (Amersham Biosciences. UK) according to the manufacturer's instructions for cloning and sequencing. The purified amplicons were ligated into a pGEM-T easy vector (Promega, USA) and transformed into

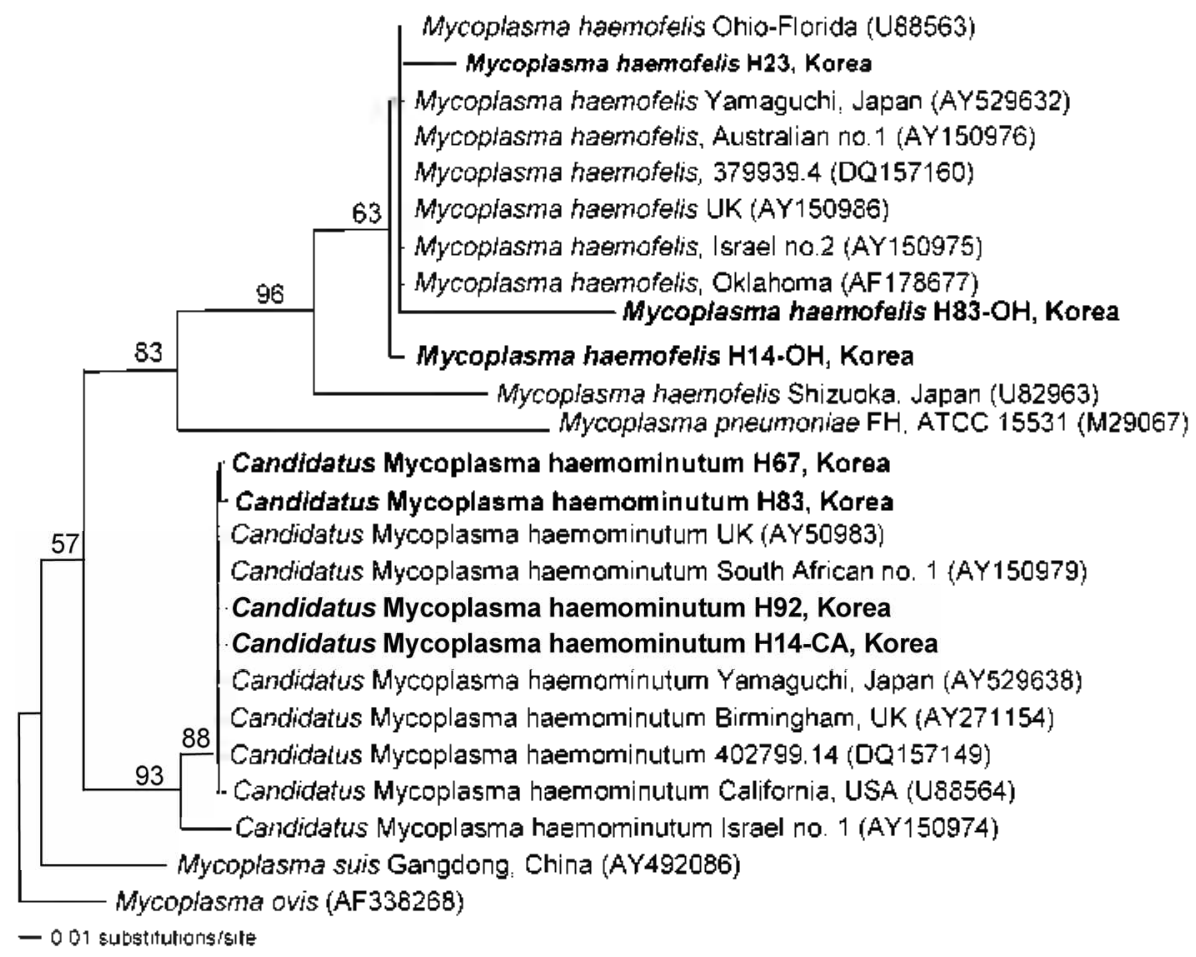

Figure 1. Phylogenetic tree based on the 16S rRNA gene sequences of hemoplasmas. The sequences of the $16 \mathrm{~S}$ rRNA gene of $M$.

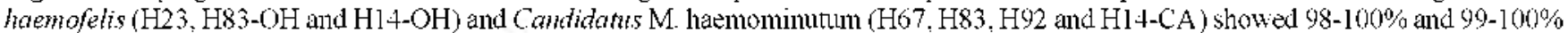
homology with the sequences of the different isolates saved in GenBank, respectively. CA. Califonia strain (Candidantus $\mathrm{M}$. haemominutum, 202-bp DNA); $\mathrm{OH}$, Ohio strain (1. f. haemofelis, 273-bp DNA ). 
TOPIOF' $E$. coli competent cells. The recombinant clones were verified by colony PCR amplification. as described above and the recombinant plasmid DNA was purified using a Wizard ${ }^{\text {(a) }}$ plus SV mini preps DNA purification system (Promega. USA). Sequencing was performed by dideoxy termination using an ABI PRISM 3700 DNA Analyzer (Applied Biosystems. USA). The sequence data was analyzed using Chromas software version. 2.31 (Technelysium. Australia). The homology searches were carried out at the National Center for Bio-technology Information (NCBI. USA) BLAST network service. The nucleotide sequences were aligned and the phylogenetic analyses were performed using the maxinuml-likelihood based on the obtained sequences (PAUP* 4.0 for Macintosh ${ }^{\mathrm{TM}}$ ).

Slab gel electrophoresis. Slab gel electrophoresis was carried out in 2\% agarose gel (Signa. St. Louis. MO, USA) with $\mathrm{I} \times \mathrm{TBE}$ buffer. Two microliters of a $6 \times$ gel loading dye (bromo phenol blue: $x y$ lene cyanol FF: glycerol $=0.25: 0.25$ : $30 . \% \mathrm{w} / \mathrm{v})$ was mixed with $10 \mu \mathrm{L}$ of each specimen. The mixture $(12 \mu \mathrm{L})$ was loaded on $6-w$ well gels and run at $150 \mathrm{~V}$ for $50 \mathrm{~min}$ in a SaB-Cell (Bio-RAD, USA). After electrophoresis. the gel was stained with $\mathrm{EtBr}(0.5 \mu \mathrm{g} / \mathrm{mL})$ for 10 $\mathrm{min}$ and de-stained in nuclease free water. The samples were then photographed under UV-light using Gel Doc 2000 (Bio-RAD. USA). The presence of the 202-bp and the 273 bp DNA bands fragment of Candidanis M. haemominutum and $M$. haemofelis, respectively. were recorded as positive results. The size of the DNA products was determined relative to those of a size marker. $i . e$. the $100 \mathrm{bp}$ DNA ladder (Bioneer. Seoul, Korea).

Microchip-based capillary gel electrophoresis. MCGE was performed on a DBCE-100 Microchip CE system (Digital Bio Technology Co., Korea) equipped with a diodepumped solid-state laser (excitation at $532 \mathrm{~nm}$ and fluorescence at $605 \mathrm{~nm}$; Power Technology Inc., Little Rock. AZ. USA) and a high-voltage device (DBHV-100, Digital Bio Techuology Co., Korea). The microchip and schott borofloat glass were purchased from Micralyne (MCBF4-TT100. Micralyne. Canada). The microchip design. gel and sample injecting procedures have been well described in our previous papers. ${ }^{14.15}$

\section{Results and Discussion}

Identification of the amplified DNA by slab gel electrophoresis. Among 331 cats, thirty four $(10.3 \%)$ proved positive for (indidunt M. haenoninutum alone, $14(4.2 \%)$ for $M$. haemofelis alone and $18(5.4 \%)$ for both organisms. Figure 2 shows representative slab gel electropherograms of the PCR results from the 11 randomly selected samples from the samples testing positive to $H$. felis. Nucleotide sequencing of the selected amplicons confinmed the PCR products to be Candidatus M. haemominutum (202-bp) and M. haemofelis (273-bp). In all cases. the sizes of the organisms were identified based on the amplicon size after slab gel electrophoresis (Fig. 2). Within the group of cat blood with suspected haemobartonellosis. PCR was positive in 11/11: 9/11

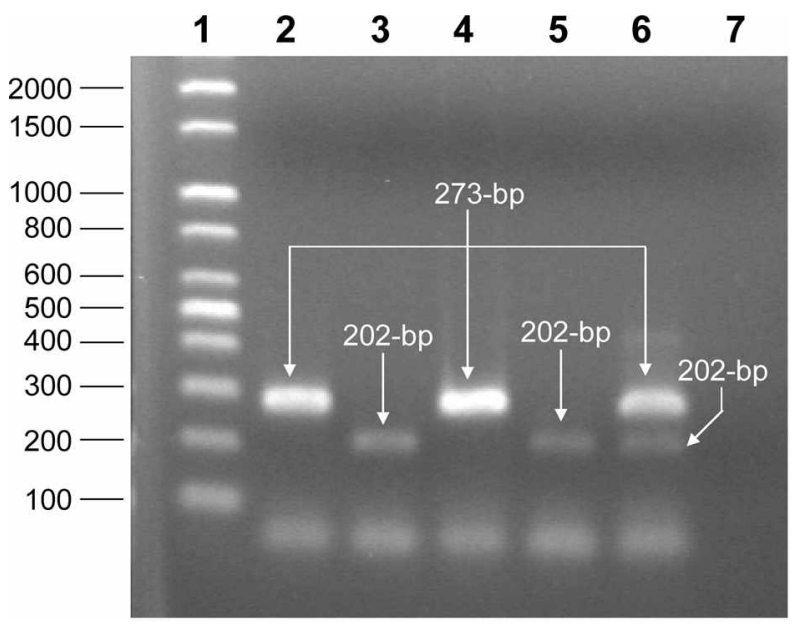

Figure 2. Representative slab gel electropherograms of the amplified PCR products for $H$. felis $16 \mathrm{~S}$ rRNA gene from the peripheral blood of cats. The lanes are as tollows: lane 1 , molecular size marker (100-bp DNA ladder): lane 2, M. hoentofelis positive control (Genbark accession no. U88563) (273-bp); lane 3, Candidatus $\mathrm{M}$. haemominutum positive control (Genbank accession no. U88564) (202-bp); lanes 4-6, each DNA tragment of positive samples; lane 7, reagent negative control. Gel electrophoresis conditions; $2 \%$ agarose gel matrix in $1 \times$ TBE buffer; applied voltage, $150 \mathrm{~V}$ for $50 \mathrm{~min}$; ambient temperature.

$(81.8 \%)$ were infected with Candidatus M. haemominutum. $5 / 11(45.5 \%)$ were infected with $M$. haemofelis and $3 / 11$ $(27.3 \%)$ were infected with both.

Microchip-based capillary gel electrophoresis. DNApolymer interactions greatly influence the separation of DNA molecules. However, PEO and PVP polymers have been studied extensively in the area of DNA analysis. ${ }^{16.18}$ Moreover. PEO and PVP have significant "self-coating" properties through adsorption to the walls. ${ }^{16}$ Therefore, PEO and PVP were selected as the sieving and coating matrix, respectively. At first glance. the effect of the sieving matrix concentration on the separation of DNA molecules in a microchip has been studied. The effect of the sieving matrix (PEO) concentration on the separation of the DNA base pairs was examined in the range from 0.1 to $0.9 \%$ and results were shown in Figure 3A. The above results show that all DNA fragments are separated within $120 \mathrm{~s}$ under an adequate resolution using the $0.3 \% \mathrm{PEO}$ gel compared with the other PEO concentrations. Meanwhile a long time was needed to elute the DNA fragments through the microchip channel with the higher concentration of sieving matrix. Therefore. the $0.3 \%$ PEO gel was selected as an optinum concentration of the sieving matrix.

The separation and migration time of the 200-bp and $300-$ bp at various electric field strengths i.e... $58.8 \mathrm{~V} / \mathrm{cm}$ to 294.0 $\mathrm{V} / \mathrm{cm}$ were also examined (Fig. 3B). This suggests that the velocity of the DNA molecules increases with increasing electric field strength. which leads to a lower resolution and poor separation between the base pairs in the DNA molecule. On the other hand. higher voltage sources increase the temperature in the microchip. which might result in broader peaks. non-reproducible migration times and sample decom- 

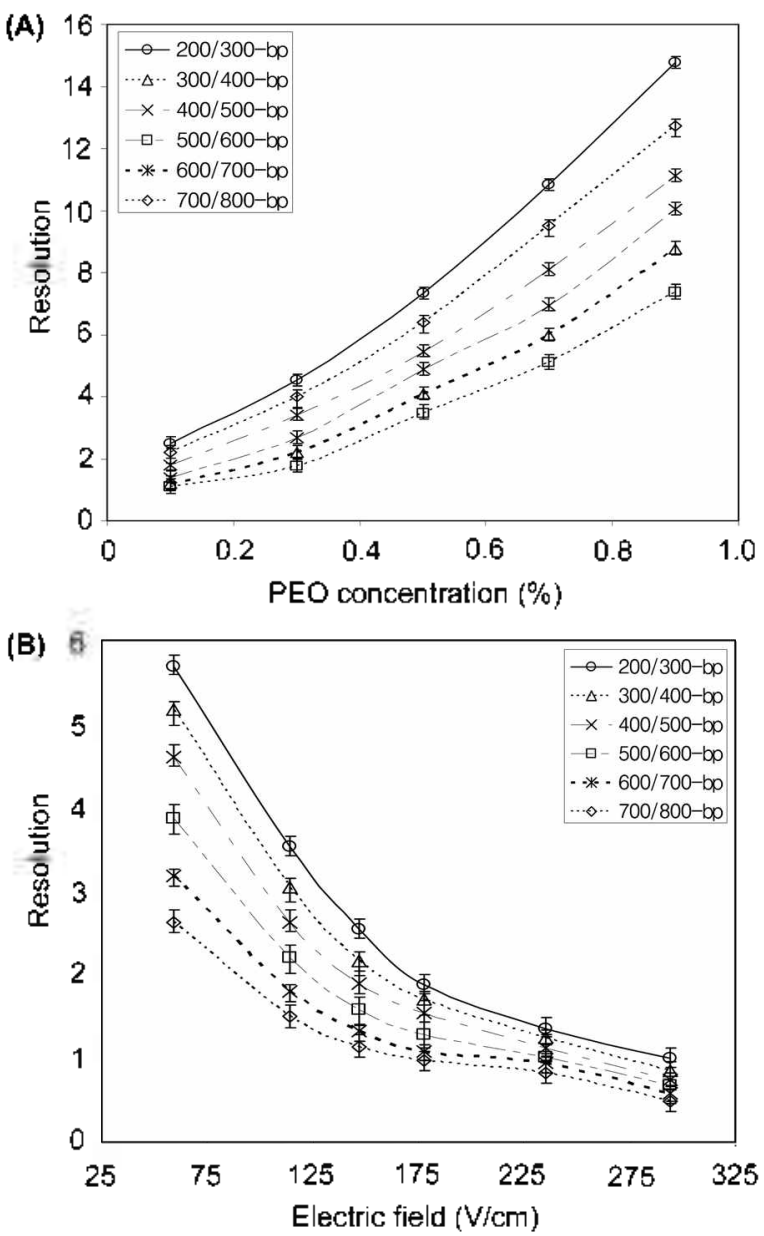

Figure 3. (A) Effect of the PEO concentration on the resolution of 200-800-bp fragments: (B) Resolution of the 200-800-bp DNA fragments as a tunction of the applied electric tield. MCGE voltage conditions; applied separation voltage, from 29.4 to $499.8 \mathrm{~V} / \mathrm{cm}$; sample, 100-bp DNA ladder: runzing buffer, $1 \times$ TBE bufter $(\mathrm{pH}$ 8.31 ) with 0.5 ppm EtBr; coating matrix, 0.5\% PVP (M l 1000 $000)$ s sieving matrix, $0.5 \% \mathrm{PEO}\left(M / M_{1} 000000\right)$.

position. This can also cause electrical discontinuity throughout the channel. which decreases the resolution and efficiency of the MCGE system. Generally in gel electrophoresis. DNA molecules can be separated according to their size by applying an electric field. Each type of DNA molecule travels through the medium at a different rate. depending on its molecular size. However chain entanglement in a sieving gel matrix also plays an important role in the separation of DNA molecules with different chain lengths in a gel with a given pore size. "This entanglement is a function of the molecular size and applied electric field. and shows irregular values in resolution. ${ }^{-1)}$ The application of a high electric field strength in capillary electrophoresis leads to a shorter analysis time and a lower separation efficiency $>800-\mathrm{bp}^{21}$ Interestingly. the separation efficiency of sniall size DNA molecules $(<300-b p)$ was decreased by applying a high constant field strength (Fig. 4B).

MCGE with PFSG The main aim of this study was ultrafast detection and differentiation of feline hemobartonellosis i.e. C'andidatus M. haemominutum of 202-bp DNA and $M$.
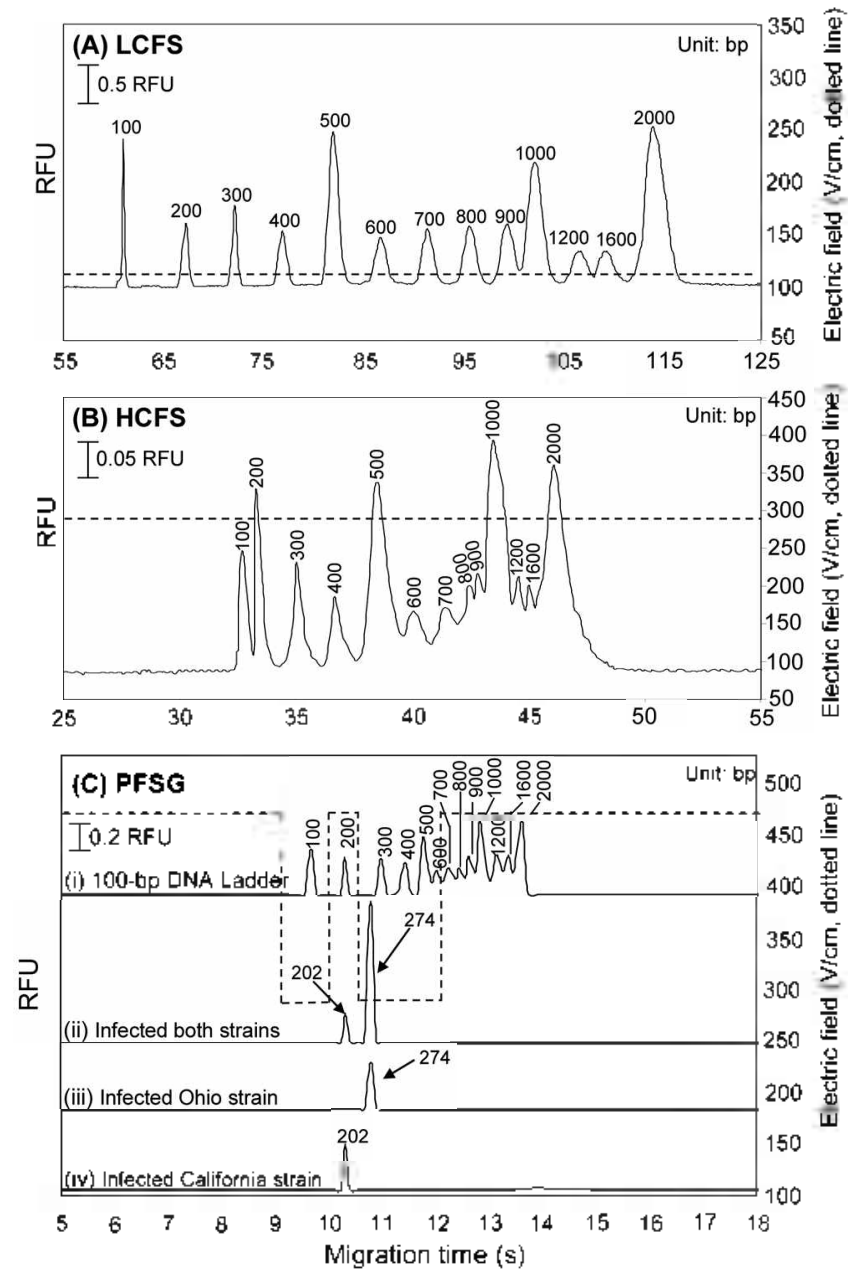

Figure 4. Representative MCGE electropherograms of the 100 -bp DNA ladder tragments under: (A) LCFS, (B) HCFS and (C) MCGE-PFSG separation and detection of the PCR products in cats suspected of having feline hemobartonellosis. (i) lo0-bp DNA ladder, (ii) PCR product of the amplified 202-bp and 274-bp DNA tragments trom the Contidatus $\mathrm{M}$. heamominutum and $M$. haemofelis infections, (iii) PCR product of the amplified 273-bp DNA fragment from an infection with 1 . haemofelis, (iv) PCR product of the amplified 202-bp DNA fragment from an infection with Condidatus M. heamominutum; MCGE condition: running buffer $1 \times$ TBE buffer ( $\mathrm{pH} 8.31$ ) with $0.5 \mathrm{ppm} \mathrm{EtBr}$ : coating matrix. $0.5 \%$ PVP $(\mathrm{h}, \mathrm{l}$ l 000000$)$ ) sieving matrix, $0.3 \%$ PEO $\left(M H_{1} 8000\right.$ 000 ); sample injection, electrokinetic injection of $56.50 \mathrm{~V} / \mathrm{cm}$ for $60 \mathrm{~s}, 100$-bp DNA ladder, microchip eftective length, $25 \mathrm{~mm}$. The dotted lines indicate the applied electric field strength.

haemofelis of 273-bp DNA in cat blood by MCGE-PFSG without any loss of resolution. More study will be needed to determine the optimum electric field strength for the rapid detection and differentiation of the feline hemobartonellosis in cats. According to our previous papers. ${ }^{14.15}$ the selected DNA fragments can be detected rapidly with adequate resolution and reduced migration time by applying a nonunifonm electric field strength. In this paper. three electric field strengths were applied for the rapid separation of the 100-bp DNA ladder (DNA size marker) such as a low constant field strength (LCFS). high constant field strength (HCFS) and programmed field strength gradients (PFSG) 
(Fig. 4). All the DNA fragments migrated within $120 \mathrm{~s}$ by applying LCFS (Fig. 4A). Under the HCFS of $294.0 \mathrm{~V} / \mathrm{cm}$. all the peaks had migrated within $49 \mathrm{~s}$ but these had poor separation and a lower resolution (Fig. 4B). This shows that the application of HCFS in a microchip causes poor separation and a low resolution between the target base pairs in DNA molecule. In PFSG the migration time of the 100bp DNA fragment was reduced by applying $470.6 \mathrm{~V} / \mathrm{cm}$ for $9 \mathrm{~s}$ and decreasing the electric field to $294.1 \mathrm{~V} / \mathrm{cm}$ for $1 \mathrm{~s}$ (Fig. 4C). After the migration of the 100-bp DNA fragments the electric field was increased to $470.6 \mathrm{~V} / \mathrm{cm}$ for $0.5 \mathrm{~s}$. In this time. 200-bp migrated with adequate resolution. The electric field was then decreased to $294.1 \mathrm{~V} / \mathrm{cm}$ for $1.5 \mathrm{~s}$ to obtain appropriate resolution between the 200-300-bp DNA fragments. After the migration of the selected base pairs. electric field was increased to $470.6 \mathrm{~V} / \mathrm{cm}$ for $20 \mathrm{~s}$, the resolution of the above base pairs was not considered in this study. The selected 100-300-bp DNA fragments migrated in ll $\mathrm{s}$ with an adequate resolution by applying PFSG (Fig. $4 C$ ). Moreover, the resolution between the 200 -bp and 300 bp DNA fragments was $2.73 \pm 0.40$, and the migration time was $10.30 \pm 0.248 \mathrm{~s}$ and $10.98 \pm 0.246 \mathrm{~s}$ at the $97 \%$ confidence interval, respectively (Table 1 ).

Application of the MCGE-PFSG method to the clinical samples. The applicability and utility of MCGE-PGSG for the rapid detection and differentiation of $\mathrm{H}$. felis in cats is described. Based on the electropherograms of the different electric field strengths (Fig. 4), it was concluded that PFSG is the best method for the rapid detection and differentiation of feline hemobartonellosis in cats. In PFSG a specific electric field was applied to the rapid separation of the specific target base pairs in the DNA ladder. This is the main advantage of PFSG over constant field strength gradients. In the PFSG electropherogram (Fig. 4C). all the target base pairs migrated within $11 \mathrm{~s}$ and the resolution of the target base pairs was $2.73 \pm 0.40$. Fig. $4 \mathrm{C}$ and Table I highlight the advantage of the PFSG method with regard to the migration time and resolution of the selected base pairs. Therefore. PFSG was selected in this study because the aim of this study is the ultra-fast detection and differentiation of haemo-

Table 1. Comparison of the PFSG method with LCFS and HCFS for the ultra-fast separation of the 200-bp and 300-bp DNA fragments in a 100-bp DNA ladder

\begin{tabular}{cccc}
\hline \multirow{2}{*}{$\begin{array}{c}\text { Applied electric } \\
\text { field (V/cm) }\end{array}$} & \multicolumn{2}{c}{ Migration time (s) } & \multirow{2}{*}{$R_{i}^{a}$} \\
\cline { 2 - 3 } & $200-\mathrm{bp}$ & $300-\mathrm{bp}$ & \\
\hline LCFS & 67.40 & 72.80 & $4.52 \pm 0.139$ \\
HCFS & 33.20 & 35.04 & $1.81 \pm 0.321$ \\
PFSG & 10.30 & 10.98 & $2.73 \pm 0.40$
\end{tabular}

Applied separation voltage. 117.6 Vicm for LCFS: $294.0 \mathrm{Vim}$ for HCFS; applied separation roltage. 470.6 V $\mathrm{cm}$ for $9 \times 294.1 \mathrm{~V} / \mathrm{cm}$ for 1 s. $470.6 \mathrm{~V} / \mathrm{cm}$ for 0.5 s. $294.1 \mathrm{~V} / \mathrm{cm}$ for $1.5 \mathrm{~s} .470 .6 \mathrm{~V} \mathrm{~cm}$ for $20 \mathrm{~s}$. run buffer $1 \times$ TBE buffer ( $\mathrm{pH} 8.31$ ) with $0.5 \mathrm{ppm}$ of EtBr: coating matrix.

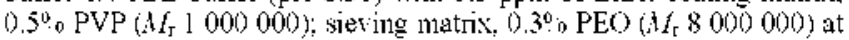
an effective length of $25 \mathrm{~mm}$. " $R_{\mathrm{s}}$ (resolution between 200 -bp and $300-\mathrm{bp}$ DNA fragments) $=\Delta t W_{\text {ace }}$ ( $\Delta t$ is the difference in migration time between two adjacent peaks: $W_{\text {ave }}$ is the arerage peak width of baseline). bartonellasis (202-bp DNA for Candidatus M. haemominutum) and (273-bp DNA for $M$. haemofelis) in feral cats within $11 \mathrm{~s}$ (Fig. 4C).

In this study, the PCR results of traditional slab gel electrophoresis and MCGE were compared to determine the potential of microchip teclunology for the rapid differentation of Canciclotus M. haemominutum (202-bp) and $M$. hoemofelis (273-bp) in feral cats. Although traditional slab gel electrophoresis is a clearly established method for examining PCR-amplified DNA fragments, there is evidence that capillary electrophoresis provides faster separation with a higher resolution. ${ }^{22}$ MCGE has attracted increasing interest as an alternative system for the analysis of DNA molecules. ${ }^{23}$ Electrophoretic analysis of the PCR products for the detection and differentiation of feline hemobartonellosis was carried out in a $2 \%$ agarose slab gel and in $0.3 \% \mathrm{PEO}$ in the microchip (Figs. 2 and $4 \mathrm{C}$ ). It should be noted that the microchip readout shows the increasing size of the PCR product from left to right. and the results obtained by the microchip is essentially the same as those obtained in the agarose gel (Fig. 4C). The detection and differentiation of the PCR products in MCGE-PFSG was much easier. and the procedure was much faster than conventional slab gel electrophoresis. The reproducibility of the method was confirmed by an analysis of the 100-bp DNA ladder, which clearly demonstrated the superiority of MCGE over the slab gel method with regard to time and sensitivity. The half-peak widths and number of theoretical plate values were $0.85 \mathrm{~s}$ and 8900 for 200-bp DNA and $0.61 \mathrm{~s}$ and 6700 for 300-bp DNA. respectively

When the MCGE-PFSG technique is applied to the analysis of the PCR products from the blood of feral cats infected with Haemobartonella felis, there was a $100 \%$ correlation between these results and those obtained using conventional slab gel electrophoresis (Table 2). However, there is considerable difficulty in identifying heterozygous

Table 2. Comparison of the MCGE-PFSG method with conventional slab gel electrophoresis for the detection of PCR products from the blood of feral cats infected with Haemobartonella felis

\begin{tabular}{|c|c|c|c|c|c|}
\hline \multirow{2}{*}{$\begin{array}{l}\text { Case } \\
\text { number }\end{array}$} & \multirow{2}{*}{$\begin{array}{l}\text { Kinds of } \\
\text { strain in } \\
\text { cat blood }\end{array}$} & \multicolumn{2}{|c|}{ MCGE-PFSG } & \multicolumn{2}{|c|}{$\begin{array}{c}\text { Slab gel } \\
\text { electrophoresis }\end{array}$} \\
\hline & & $\mathrm{CA}^{a}$ & $\mathrm{OH}^{b}$ & $\mathrm{CA}^{a}$ & $\mathrm{OH}^{t_{1}}$ \\
\hline $\mathrm{HI} 4$ & $\mathrm{CA} / \mathrm{OH}$ & + & + & + & + \\
\hline $\mathrm{H} 23$ & $\mathrm{CA} / \mathrm{OH}$ & $\mathrm{ND}^{c}$ & + & $\mathrm{ND}^{r}$ & + \\
\hline $\mathrm{H} 58$ & $\mathrm{CA} / \mathrm{OH}$ & + & + & + & + \\
\hline $\mathrm{H} 6 \mathrm{I}$ & $\mathrm{CA} / \mathrm{OH}$ & + & $\mathrm{ND}^{\mathrm{C}}$ & + & $\mathrm{ND}^{\mathrm{c}}$ \\
\hline $\mathrm{H} 64$ & $\mathrm{CA} / \mathrm{OH}$ & + & $\mathrm{ND}^{r}$ & + & $\mathrm{ND}^{c}$ \\
\hline $\mathrm{H} 65$ & CA & + & $\mathrm{ND}^{\mathrm{r}}$ & + & $\mathrm{ND}^{\mathrm{c}}$ \\
\hline $\mathrm{H} 66$ & CA & + & $N D^{x}$ & + & $\mathrm{ND}^{c}$ \\
\hline $\mathrm{H} 67$ & CA & + & $N D^{x}$ & + & $\mathrm{ND}^{c}$ \\
\hline $\mathrm{H} 70$ & $\mathrm{OH}$ & $\mathrm{ND}^{c}$ & + & $\mathrm{ND}^{r}$ & + \\
\hline $\mathrm{H} 83$ & $\mathrm{CA} / \mathrm{OH}$ & + & + & + & + \\
\hline $\mathrm{H} 92$ & CA & + & $\mathrm{ND}^{\mathrm{C}}$ & + & $\mathrm{ND}^{c}$ \\
\hline
\end{tabular}

${ }^{\circ} \mathrm{CA}$ : Califonia strain (Codidontus M. haemominutum, 202-bp DNA). "OH: Ohio strain (1. hacenofelis, 273-bp DNA). TND: Not detected. 
DNA molecules with slab gel electrophoresis. ${ }^{7}$ Funally. MCGE-PFSG technology is a good alternative to conventional methods for the ultra-fast detection and differentiation of feline hemobartonellosis in cats as well as other clinical diagnostics.

\section{Conclusions}

MCGE-PFSG was introduced in order to increase the separation efficiency between the target DNA fragnients with a specific size and reduce the migration time for the rapid detection and differentiation of feline hemobartonellosis through the application of a non-uniform electric field in MCGE system. PFSG vastly inproves the resolution $\left(R_{s}\right.$ $>2.7$ ) and migration time ( $<11 \mathrm{~s}$ ) for the separation of specific size DNA fragments (i.e.. 200-bp and 300-bp) compared with the HCFS. The differentiation of feline hemobartonellosis i.e., Candidanis M. haemominutum (202bp) and $M$. horemofelis (273-bp) can be acconiplished with greater speed and simplicity using MCGE by applying PFSG than the currently available teclnologies. The sensitivity. speed, sinplicity and reagent consumption of the MCGE with PFSG technology holds great potential for extrapolation to the detection and differentiation of mutations in DNA with a similar molecular biology. which makes it attractive for use in a clinical diagnostic laboratory.

Acknowledgements. The authors wish to thank Dr. Jinho Park for supplying the real samples. This work was supported by a grant from the Post-Doc. Program. Chonbuk National University (2006), Jeonju, South Korea and by a grant from Korea Ministry of Science and Teclnnology (M1053608003-05N3608-00310).

\section{References}

1. Flint. I. C.: Roepke. M. H.: Jensen. R. Ant. J. Tét. Res. 1958. 19. 164.

2. Berent. L. M.: Messick. T. B.: Cooper. S. K. Am. J. Jet. Res. 1998. 59. 1215 .

3. Tasker. S.: Lappin. M. R. J. Feline Hed. Surg. 2002. 4. 3.

4. Inokuma H.: Taroura, S.; Okuda, M.; Hisasue, M; Itamoto, K: Une. S.: Nakaichi. M.: Taura. Y. J. Jet. Hed Sci. 2004. 66. 1017.

5. Watanabe. M.: Hisasue. M.: Hashizaki. K.: Furuichi. M.: Ogata. M.: Hisamatsu. S.: Ogi. E.: Hasegawa. M.: Tsuchiya. R.: Yamada. T. J. Fet. Ifed. Sci. 2003. 65. 1111 .

6. Kewish. E. K.: Appleyard. D. G; Myers. L. S.; Kidney. A. B:; Jackson, L. M. Can. Iet. J. 2004. 45. 749.

7. Tian1. H.: Brody. L. C.: Landers. I. P. Genone Research 2000. 10. 1403.

8. Dolnik. V.: Liu. S. J. Sep. Sci. 2005. 28. 1994.

9. Kang. S. H.: Jang, S.: Park. S.-G.; Bull Rorean Chem. Soc. 2006. 27. 1346 .

10. Jang. S.: Cho, K.: Chae, J.S.: Kang, S. H. Bull. Koman Chem Soc. 2004.25 .757$.

11. Sung. W. C.: Lee. G. B.: Tzeng. C. C.: Chen1. S. H. Electrophoresis 2001. 22. 1188 .

12. Baba. Y. J. Chronatogr: B 1996. 687.271.

13. Ronai. Z; Barta. C.: Sasvari-Szekely, M.: Guttman, A. Electophoresis $2001,22.294$.

14. Kang. S. H.: Park. M.: Cho. K. Electrophoresis 2005. 26. 3179.

15. Kim. Y. J.: Chae. J. S.: Chang. T. K.: Kang. S. H. J. Chrontatogr. A 2005. 1083.179.

16. Fung. E. N.: Yeung. E. S. Anal Chem 1995. 67. 1913.

17. Chang. H. T: Yeung. E. S. J. Chronatogr B 1995. 669.113

18. Gao. Q.: Yeung, E. S. Anal. Chem. 1998, 70. 1382.

19. Snisek. D. L.: Hoagland. D. A. Science 1990. 2+8. 1221.

20. Demana. T.: Lanan. M.: Morris. M. D. Anol. Chen. 1991. 63. 2795.

21. Guttman, A.: Wanders. B; Cooke, N. Anal Chem 1992, 64, 2348.

22. Dolnik, V: Liu. S. J. Sep. Sci. 2005, 28. 1994.

23. Oda. R. P. Bush, V. J.: Landers, J. P. Hand Book of Capillay Electrophoresis. $2^{\text {nd }}$ ed.: CRC Press: Boca Raton. 1997: p 673. 